\title{
Women Residents' Quality of Life in the Shophouse in Medan, Indonesia
}

\author{
Wahyuni Zahrah, Nurlisa Ginting, Dwira N. Aulia, Amy Marisa \\ Department of Architecture, Faculty of Engineering, \\ Universitas Sumatera Utara, Medan, Indonesia \\ Wahyuni.zahra@usu.ac.id, nurlisa@usu.ac.id, dwira.nirfalini@usu.ac.id, amy@usu.ac.id \\ Tel: +6281361238982
}

\begin{abstract}
In Medan, Indonesia, shop houses are famous buildings, though they have spatial and thermal comfort limitations. This investigation aims to find out the essence of shop house women residents' quality of life. This research is a qualitative study with a phenomenological approach. The collection of data used in-depth interviews with seven women dwellers. The research indicates that the quality of life in women's view is not determined by mere material abundance, but rather by feeling sufficient and gratitude. This research can contribute to enriching the quality of life and built environment studies of urban mixed-use living.
\end{abstract}

Keywords: shop house; quality of life; women; mixed-use living

eISSN: 2398-4287@ 2020. The Authors. Published for AMER ABRA cE-Bs by e-International Publishing House, Ltd., UK. This is an open access article under the CC BYNC-ND license (http://creativecommons.org/licenses/by-nc-nd/4.0/). Peer-review under responsibility of AMER (Association of Malaysian Environment-Behaviour Researchers), ABRA (Association of Behavioural Researchers on Asians) and cE-Bs (Centre for Environment-Behaviour Studies), Faculty of Architecture, Planning \& Surveying, Universiti Teknologi MARA, Malaysia. DOI: https://doi.org/10.21834/ebpj.v5i15.2495.

\subsection{Introduction}

Various literature stated that quality of life is a complex concept. There is no one fixed standard to define the quality of life (Massam, 2002). However, scholars agree that human life's quality is interrelated with its objective environment, including houses. The shophouse is a typology of mixed-function housing. It already exists since $900 \mathrm{BC}$ (Corni, 1993) and continues to be built today. Several works address numerous advantages of shophouses, including flexible space, unique façades (Puspitasari and Handjayani, 2016; Eddy et al., 2020), and pedestrian-oriented designs (Davis, 2014; Wan Ismail, WH, \& Ching, LH (2016). Research that focuses on building science notes several problems, including thermal comfort (Dang and Pitts, 2017; Zakaria et al., 2015) and spatial comfort (Sari, 2018; Ginting et al., 2018). Among these advantages and disadvantages, there are minimal studies that emphasize residents' quality of life. However, they are the ones who feel the most 'consequences' of all the physical designs of shophouses, particularly women. Scholars agree that they have significant family life roles (Ellen and Amadu, 2018; Zereyesus et al., 2017; Salehi-Isfahani and Taghvatalab, 2016; Falola et al., 2020) and in deciding on homeownership and design (Farago, 2015).

\subsection{Aim of the study}

The study aimed to investigate women residents' quality of life through their experience of dwelling in shophouses.

\subsection{The objective of the study}

The objective of the study was to describe women residents' motivation for living in the shophouse. Furthermore, the investigation means to formulate the essence of their quality of life during the inhabiting.

eISSN: 2398-4287C 2020. The Authors. Published for AMER ABRA cE-Bs by e-International Publishing House, Ltd., UK. This is an open access article under the CC BYNC-ND license (http://creativecommons.org/licenses/by-nc-nd/4.0/). Peer-review under responsibility of AMER (Association of Malaysian Environment-Behaviour Researchers), ABRA (Association of Behavioural Researchers on Asians) and cE-Bs (Centre for Environment-Behaviour Studies), Faculty of Architecture, Planning \& Surveying, Universiti Teknologi MARA, Malaysia.

DOI: https://doi.org/10.21834/ebpj.v5i15.2495 


\subsection{Literature Review}

The quality of human life is related to the environment in which they live, including home (Das, 2008; Seamon, 2017). A house is a place where life necessities are fulfilled, both physically and psychologically (Rapoport, 2006; Sharvimaki, 2006 Heidegger in Sharr, 2007; Seamon, 2017). The shape and typology of the house can vary, which comes from the needs of its users. One of the typologies of houses found in various cities is a mixed-use building: residence and business area in one structure. The term can vary, such as Japanese and China shop houses, northern European merchants' houses, English terraced houses, and American small town corner stores with apartments at the upper level (Davis, 2014). Buildings like this in Indonesia come from northern China shop houses' typology, but it is different from the original one with an inner court. This feature is no longer present in many shophouses built in Medan, Indonesia (Zahrah, 2016). Several studies note that shop house design has lacked spatial and thermal comfort (Sari, 2018; Ginting et al., 2018 Dang and Pitts, 2017; Zakaria et al., 2015). On the other side, the facade designs, especially those that still retain Chinese shop houses' distinctive architectural features, are considered attractive and valuable (Puspitasari and Handjayani, 2016; Eddy et al.). Narrow alleys as social spaces, spatial flexibility, and pedestrian-oriented designs give shop houses more value (Tirapas and Suzuki, 2013; Tirapas and Boonyachurt, 2013; Wan Ismail and Ching, 2016). Analysis of shop houses indicates that this typology is considered acceptable from the exterior and urban space aspects. From the interior elements, apart from space flexibility, the shophouses have weaknesses. It should be noted that it is in this inner space that the residents live. However, there are minimal studies that focus on the occupants' point of view. In fact, they are the most important actors that should be known about their life in that place, whether pleasant or not. How is their quality of life while living in the shophouse? One of the most appropriate ways to investigate this is to explore someone's experience of inhabiting and how it relates to the attainment of quality of life (Sarvimaki, 2006; Seamon, 2017).

Studies on quality of life note that family life is an essential indicator of life achievement (Camfield, 2006). Together with the man (father), as the head of the family, the mother (woman) also has significant roles (Osei-Tutu1 and Ampadu, 2018; Pangaribowo, 2018). Empirical studies explain that women and men have differences in achieving quality of life (Chui and Wong, 2016). Women often face challenges in carrying out their dual roles, namely as the primary control for family life and as the person who has social responsibility in the public sphere. Several explorations state that this dual role causes the different quality of life between working women and housewives (Ahmad and Khan, 2018). However, very few studies have looked at women's quality of life concerning mixed-function occupancy typologies. It is interesting that, in a shophouse, the combination of business and domestic activities that are united in one building provides opportunities for women to move quickly in carrying out their double duties. This condition raises several questions: what is their motivation to live in the building? Does the relatively limited space meet their needs? Is the expected quality of life achieved? The answers to these questions are expected to provide insight into the relationship between the built environment and the women's quality of life, based on several women's experiences living in shophouses in Medan, Indonesia.

\subsection{Methodology}

The study used a qualitative method with a phenomenological approach based on participants' real and original experiences in undergoing a phenomenon (Seamon, 2017). The study's phenomenon is life in shophouses, a mixture of both houses for family living and business.

\subsection{Setting}

The study was conducted from June until August 2020 in seven shophouses in Medan city, Indonesia. The building was chosen purposefully with the following criteria:

- occupied as a permanent residence, not temporarily

- be inhabited for at least five years

- occupied as a complete family residence

- owned, not rented, or loaned

- designed only by residents, not on the role or interference of an architect

\subsection{Participants}

The study participants were seven adult women who have lived in their shophouses for more than five years and were already married.

\subsection{Data Collection}

Data were collected through face to face interviews using an interview guide. The aspects asked were the motivation to live in the shophouse and the meaning and achievements of life quality while living in the building. Each participant was interviewed once, for a duration of 28 to 45 minutes. Interviews were recorded in video and audio, then transcribed verbatim.

\subsection{Data Analysis}

The study used a structured phenomenological analysis method based on Moustakas (2014). The first step taken was transcribing the results of the interview. The manuscript was then read over and over again to capture the overall results of the interview. Next, an epoche was carried out to reveal the researcher's experience of the shophouse phenomenon being studied. The next step was to collect essential statements from participants. Then, the comments were equalized (horizontalization), where the words with similar meanings 
were eliminated. A list of meanings was obtained from this stage, which was then described texturally (what was felt) and structurally (details of the participant's statement).

\subsection{Interpretation}

The analysis results are the essence of the meaning of women's quality of life during their dwelling in shophouses.

\subsection{Findings}

\subsection{Participants characteristics}

All participants were adult women aged 35 - 55 years. All of them were housewives who ran a business in their shop, both as a side job or the primary income resources. The latter type was usually operated together with the husbands. Five of the seven participants had previously lived in a shophouse, and two others once lived in a row-single-story building. (Table 1).

\begin{tabular}{|c|c|c|c|c|c|c|c|}
\hline No & Name $^{*}$ & Education & $\begin{array}{l}\text { Age } \\
\text { bracket }\end{array}$ & Business/job & $\begin{array}{l}\text { The income per } \\
\text { month (million } \\
\text { IDR) }\end{array}$ & $\begin{array}{l}\text { Dwelling } \\
\text { shop house } \\
\text { since }\end{array}$ & $\begin{array}{l}\text { House type before dwelling } \\
\text { current shop house }\end{array}$ \\
\hline 1. & Mrs. Yeni & Senior high school & $46-55$ & Restaurant & $<5$ & 1994 & Shophouse \\
\hline 2. & Mrs. Mila & Bachelor degree & $46-55$ & Restaurant/teacher & $10-15$ & 1998 & Single story house \\
\hline 3. & Mrs. Rina & Bachelor degree & $46-55$ & Kitchenware accessories & $<5$ & 2002 & $\begin{array}{l}\text { Single story house, shop } \\
\text { house }\end{array}$ \\
\hline 4. & Mrs. Caca & Senior high school & $46-55$ & Rental space & $<5$ & 1980 & Shophouse \\
\hline 5. & Mrs. Nina & Senior high school & $46-55$ & $\begin{array}{l}\text { Machine equipment and } \\
\text { workshop }\end{array}$ & $10-15$ & 1992 & Shophouse \\
\hline 6. & Mrs. Ami & Senior high school & $46-55$ & Building material store & $10-15$ & 2002 & Single story house \\
\hline 7. & Mrs. Eva & Bachelor degree & $36-45$ & Kids private school-lesson & $5-10$ & 2012 & Shophouse \\
\hline
\end{tabular}

*not real name

Source: Survey, 2020

\subsection{Motivation to dwelling in the shophouse}

The motivation to dwelling in shop houses varies for each participant. There were four reasons they stated, as mentioned in Table 2.

Table 2. Participants' motivation to dwelling in the shophouse

\begin{tabular}{rll}
\hline & Motivation & Participants \\
\hline 1 & Dwelling in shop house due to marriage & Mrs. Mila, Mrs. Caca, Mrs.Nina \\
\hline 2 & Dwelling in shophouse to running a business & Mrs. Ami, Mrs. Yeni \\
\hline 3 & Dwelling in shop house due to the affordability & Mrs. Rina, Mrs. Eva \\
\hline 4 & Dwelling in shop house due to location & Mrs. Rina, Mrs. Eva \\
\hline & Source: Survey and analysis, 2020
\end{tabular}

Dwelling in shop house due to marriage

Three of the seven participants occupied the shop house due to the marriage, namely Mrs. Caca, Mrs. Mila, and Mrs. Nina. They married a man who had to continue his parents' business by staying with and caring for them in their homes. These women had to enter and live in inherited shop houses and help their husbands run their businesses. Those who lived in these heritage buildings had parent inlaws and lived together with them. These buildings were inhabited by three generations, grandmothers and grandfathers, children and children in-laws, and grandchildren.

Dwelling in shophouse to running a business

Participants who lived in the shophouses to running a business are Mrs. Ami and Mrs. Yeni. Before living in this building, Mrs. Yeni, stayed in a shophouse in the city center and ran a stationary grocery business. Over time, Mrs. Yeni's business turned into a restaurant. Before living in her own shophouse, Mrs. Ami ran her business in a rental shop that was only used for trading but lived in a different building. Bu Ami described the hassles of living in two separate buildings every day.

"We could not move fast if the shop were separated from the house... it was a bit complicated, the road jammed ... yes ... the history (of living here) ... the first was because looking for a building for trading." (Mrs. Ami)

"I used to live in row single-story house. Just because it was not wide enough, it is better to stay at a shophouse like this." (Mrs. Rina)

"What we mean is that we can use it for commercial purposes ..." (Mrs. Yeni)

Dwelling in shop house due to the affordability

The shophouse was the choice of Mrs. Rina and Mrs. Eva to live because the price was more affordable than the villa type building.

"Incidentally, one day, my husband's cousin offered him. The building was under-utilized, so he asked whether my husband wished to own it. 
Coincidentally, the offer was inexpensive. (Mrs. Eva)

"... It is about budget too. If we had enough finances at that time, we would look for something bigger ..." (Mrs. Rina)

Dwelling in shop house due to location

$\mathrm{Bu}$ Ami, Bu Rina, and Bu Eva decided to live in the shop they are currently occupying due to location considerations. Mrs. Ami and her husband consider the prospective location in developing their business because of its location on an inter-city highway. Meanwhile, Mrs. Rina chose her shophouse location because it is close to her husband's office. Mrs. Eva, who previously was a private school teacher, was considering a place close to where she worked.

"Because my husband wants to buy a house that is not far from his office, not far from the city center, that is why we were looking for a house around here. If the housing complex is a bit far away, though, maybe I can get villas types that I more preferable."(Mrs. Rina)

\subsection{Quality of life}

All participants stated that they achieved their desired quality of life while living in the shophouse. Table 3 shows the quality of life characters put forward by the participants.

\begin{tabular}{lll}
\multicolumn{3}{c}{ Table 3. Participants' quality of life characters } \\
\hline & Quality of life & Participants \\
\hline 1 & Economic sufficiency & Mrs. Rina \\
\hline 2 & Health & Mrs. Ami, Mrs. Rina, and Mrs. Nina \\
\hline 3 & Children success & Mrs. Yeni, Mrs. Mila, Mrs. Caca, Mrs. Nina, Mrs. \\
& & Ami \\
\hline 4 & Gratitude & Mrs. Ami, Mrs. Eva, Mrs. Nina, Mrs. Rina, Mrs. Mila \\
\hline & & Source: Survey and analysis, 2020
\end{tabular}

\section{Economic sufficiency}

Fulfilled economic needs are an indicator of the quality of life, according to all participants. The fulfillment was supported directly or indirectly by the shophouse business. Those whose primary family income was derived from running a business in their shops ran the business with their husbands. Those who operated side businesses also supported family income; directly through their side business, indirectly through efforts to close the distance between the house and the husband's workplace.

"(Quality life) when we can live in our own house, close to everywhere, can be used for business too.... It has been achieved, we have been given an economic condition that is adequate now. "(Mrs. Rina)

\section{Health}

According to Mrs. Ami, Mrs. Rina, and Mrs. Nina, health is an essential indicator of the quality of life. This condition is pursued by a healthy lifestyle, nutritious food, positive thoughts, and exercise. These women shopped and cooked themselves a meal for the whole family to eat. They did it every morning before opening the shop. The existing kitchen was considered adequate for this activity.

"A quality life, in my opinion, the most important thing is to be given health. Because how much your treasure is if you are not healthy, you cannot do anything. "(Mrs. Rina)

"(Quality life) yes everything is fulfilled... yes, health, family gatherings ... It has been achieved." (Mrs. Nina)

"(Quality life) we have been given health and economic conditions that are adequate now ... It has been (achieved)." (Mrs. Rina)

"As I said, health, at most number one for me ..." (Mrs. Ami)

\section{Children success}

Other than Mrs. Eva, who had children that still in elementary school age, six other participants stated that successful children were the indicator of the quality of life. Bu Ayen has a child that had finished college, had a family, had a permanent residence and job, and had given her grandchildren. Mrs. Caca and Mrs. Ami had children who have worked but were not yet married. Bu Mila, Bu Ayen, Bu Ami, and Bu Nina had children who were still in college or high school, and so far, their education went well. Overall, all of the participants were satisfied because they could send their children to university and achieved a self-supporting life.

"...The important thing is that children can develop their business." (Mrs. Yeni)

"... My daughter has become a staff in business administration... My son works in insurance office..." (Mrs. Mila)

"... The children are grown, they are independent ... The important thing is that the children have adequate education ..." (Mrs. Caca)

"....It has been achieved... My daughter becomes a medical doctor ... "(Mrs. Nina)

"... Yes we are happy to see our children are grown, it has achieved, hopefully ... the children grow well, study well, study hard... obedient kids... (Mrs. Ami)

\section{Gratitude}

Most participants mentioned that gratitude was the indicator of achieving quality of life. This feeling was expressed by accepting everything owned with an open and happy heart, even though it had not reached the ideal conditions. 
"(Quality life) .... I do not have many demands, say a small car, fine, a small house, okay." (Mrs. Eva)

"(Quality life) yes everything is fulfilled... the important thing is... yes, be grateful ... yes we are religious people." (Mrs. Nina)

"(For having this shophouse) I'm grateful..." (Mrs. Mila, Mrs. Rina)

\section{Discussion}

Architecture can be interpreted as a built environment where humans were doing activities to fulfill their daily needs. Thus, their quality of life is maintained and ultimately happy (Seamon, 2017; Heidegger in Sharr, 2007; Rapoport, 2006). This study points out that women who live in shophouses have achieved what they want about the quality of life, namely a sufficient level of the economy, health, children's independence, and gratitude. The participants' preferences and attainments represent most Southeast Asian people related to family and religious life (Camfield, 2006). Most of the participants are women with multiple roles, running a business with their husbands and taking care of their own families. With these conditions, the quality of life they desire is achieved. Some participants stated that living in a shop house made these two roles easier than a separate home and shop building. This condition is in line with previous research that women who work have better life satisfaction than housewives (Milkie \& Peltola, 1999).

According to their cultural background, experiences, and personal goals, everyone's life needs vary. (Sagiv et al., 2017). This study provides an overview of the various needs of occupying a shophouse. Some decide to live in a shophouse to run a business that was intended from the start. Others are more due to easy access, low prices, and the consequences of marriage. Whatever their motivation and reasons, participants who stayed at the shophouse indicated that living in the shophouse, directly or indirectly, supported them to meet their needs. It can be concluded that this building typology has a positive influence on achieving quality of life. Living in a shophouse is a necessity for some people to carry out what they aspire. They can work and earn money as well as care for families and lead children to independence. Both of these are prioritized.

Consequently, they accept staying in a building with limited area, limited windows, and without a yard. This fact proves that women who live in shop houses successfully cope and adapt to their environment. Therefore, when asked whether all these limitations were obstacles, they said they were not. All participants stated that the quality of life was fulfilled while living in the place. This fact provides an additional view of shophouse typology and complements previous research on the building's design limitations.

However, for some individuals, choosing a particular building type to become their homes generates a consequence of accepting all conditions. The women satisfied with their shophouses were similar to the other residents with different house types (such as apartments, single building houses, and row houses). Most of them were satisfied with their homes (Martsin and Niits, 2018). The other study shows that the level of satisfaction may vary in different building typologies. The research in Chicago, for example, indicates that residents in downtown high rise-higher density housing have a higher satisfaction level than those in suburban low rise housing (Du et al., 2017).

\subsection{Limitation of Study}

Participants in this study were the Chinese community, who had a historical tradition of living in shophouses from generation to generation. This fact is one logical reason that life in the building can be lived more easily. Further research can be carried out on participants who do not have a historical background of living in shophouses to get more insight into how they cope with building limitations and whether it supports their quality of life. This investigation also does not get many details of how the women cope and adapt to their environment. It is recommended to continue studying this aspect from a behavioral-architecture perspective.

\subsection{Conclusion and recommendation}

This study found that the essence of women's quality of life in shophouses is the achievement of economic independence, health, children's success and independence, and gratitude. This achievement is supported by the condition of shophouses that accommodate both work and residence function, although several studies have noted that these buildings are less comfortable. This study also supports previous research on women's quality of life who can play a dual role, particularly in a mixed-use building context. This study's results serve as a reference in urban and building planning, especially in Indonesia, in 'accepting and managing' this fast-growing typology due to its positive effect in supporting women's quality of life.

\section{Acknowledgments}

The study was carried out with financial support from the DRPM Grant-scheme 2020 of the Ministry of Education and Culture, Indonesian Republic. All of the participants are thankfully acknowledged.

\section{Paper Contribution to Related Field of Study}

The study contributes to enrich women's quality of life studies concerning inhabiting mixed-use building phenomena, particularly in developing country cities. 


\section{References}

Camfield, Laura (2006). The why and how of understanding subjective wellbeing: exploratory work by the WeD Group in four developing countries, WeD Working Paper 26, Bath, UK: ECRC

Chui, W. H., \& Wong, M. Y. H. (2016). Gender Differences in Happiness and Life Satisfaction among Adolescents in Hong Kong: Relationships and Self-Concept. Social Indicators Research. https://doi.org/10.1007/s11205-015-0867-z

Corni, Fransesco (1993). Umm El Madayan, an Islamic City through the Ages, Boston: Houghton Mifflin Company

Dang, H. T., \& Pitts, A. (2017). Influences of building and urban typologies on the study of thermal comfort in "shophouse" dwellings in Ho Chi Minh City, Vietnam. Proceedings of 33rd PLEA International Conference: Design to Thrive, PLEA 2017

Das, D. (2008). Urban quality of life: A case study of Guwahati. Social Indicators Research. https://doi.org/10.1007/s11205-007-9191-6

Davis, H. (2012). Living over the Store: Architecture and Local Urban Life. New York: Routledge.

Du, P., Wood, A., Ditchman, N., \& Stephens, B. (2017). Life satisfaction of downtown High-Rise vs. Suburban low-rise living: A Chicago case study. Sustainability (Switzerland). https://doi.org/10.3390/su9061052

Eddy, F., Lindarto, D., Harisdani, D. D., \& Abdillah, W. (2020). The shophouse facade as a former of Medan City character identity. IOP Conference Series: Earth and Environmental Science. https://doi.org/10.1088/1755-1315/452/1/012043

Falola, Abraham; Fakayode, Segun Bamidele; Kayode, Ajoke Oluwatoyin; Amusa, Mujidat Adeola, (2020), Rural Women in Kwara State (Nigeria) and their Contributions to the Welfare of their Households, Journal of International Women's Studies. 2020, Vol. 21, Issue 6, p170-183. 14p

Farago, Peter (2015). Why women are the key decision makers in real estate? https://www.news.com.au/why-women-are-the-key-decision-makers-in-real-estate/newsstory/31b0a88b68a8231ca2a99e489688f4a9, accessed 22 October 2020

Ginting, Y. U. U., Ginting, N., \& Zahrah, W. (2018). The spatial comfort study of shophouse at Kampung Madras. IOP Conference Series: Earth and Environmental Science. https://doi.org/10.1088/1755-1315/126/1/012008

Hale, Jonathan (2017). Merleau-Ponty for Architects, London and New York: Routledge

Märtsin, Mariann, and Niit, Toomas (2018). The Home as a Territorial System (II) 1, in Housing, Space and Quality of Life, Mira, Ricardo García and Uzzell, David L (ed), New York: Routledge.

Massam, B. H. (2002). Quality of life: Public planning and private living. In Progress in Planning. https://doi.org/10.1016/S0305-9006(02)00023-5

Osei-Tutu, E. M., \& Ampadu, E. (2018). Dimensions of couples' decision-making at home: The Ghanian experience. Journal of International Women's Studies. Vol. 19, No. 2 January 2018

Pangaribowo, E. H., Tsegai, D., \& Sukamdi (2019). Women's bargaining power and household expenditure in Indonesia: the role of gender-differentiated assets and social capital. GeoJournal. https://doi.org/10.1007/s10708-018-9901-4

Peltola Pia (1999). Playing All the Roles: Gender and the Family Balancing Act. Journal of Marriage and Family, 61 (2): 476-90.

Puspitasari, Popi; Handjajanti, Sri, (2016), Precedent studies and visual architecture research: in search of theoretical concept of Chinese shophouse façade style (Case: Kampung Cina, Pekalongan, Central Java, Indonesia), Proceeding International Seminar on Livable Space, 156-162

Sagiv, L., Roccas, S., Cieciuch, J., \& Schwartz, S. H. (2017). Personal values in human life. Nature Human Behaviour. https://doi.org/10.1038/s41562-017-0185-3

Salehi-Isfahani, D., \& Taghvatalab, S. (2019). Education and the allocation of time of married women in Iran. Review of Economics of the Household. https://doi.org/10.1007/s11150-018-9407-3

Sari, L. H., Yuzni, S. Z., Haiqal, M., \& Evalina, Z. (2018). A review of spatial comfort in shophouse in humid tropics. IOP Conference Series: Materials Science and Engineering. https://doi.org/10.1088/1757-899X/352/1/012066

Sarvimäki, Anneli (2006). Wellbeing as being well-a Heideggerian look at wellbeing, International Journal of Qualitative Studies on Health and Well-being, 1:1, 4-10, DOI: $10.1080 / 17482620500518101$

Seamon, D. (2017). Architecture, Place, and Phenomenology: Buildings as Lifeworlds, Atmospheres, and Environmental Wholes. Place and Phenomenology, Janet Donohoe, Editor.

Sharr, Adam (2007). Heidegger for Architects (Thinkers for Architects), London and New York: Routledge

Tirapas, Chamnarn, Boonyachut, Supawadee (2013). Flexibility Survey of Bangkok Shophouses for Mixed-Use Development. www.arch.kmutt.ac.th accessed August 8 , 2020

Tirapas C and Suzuki, K (2013). Bangkok Shop House Support Design for Accommodating Changes and Future Mixed-Use Building. 12 Th International Congress Asian Planning Schools Association. 1-3 Nov. 2013, National Taiwan University. Taiwan

Wan Ismail, W. H., \& Ching, L. H. (2016). Back Lanes as Social Spaces in Chinatown, Kuala Lumpur. Environment-Behaviour Proceedings Journal, 1(3), $293-299$. https://doi.org/10.21834/e-bpj.v1i3.373 
Zahrah, W., et.al., AIVCE-BS-2, 2020ShahAlam, cE-Bs, FSPU, Universiti Teknologi MARA, Shah Alam, Malaysia, 02-03 Dec 2020, E-BPJ, 5(15), Dec 2020 (pp.395-401)

Zereyesus, Y. A., Amanor-Boadu, V., Ross, K. L., \& Shanoyan, A. (2017). Does Women's Empowerment in Agriculture Matter for Children's Health Status? Insights from Northern Ghana. Social Indicators Research. https://doi.org/10.1007/s11205-016-1328-z 